\title{
A LEARNER'S GRAMMAR FOR ESTONIAN: INSIGHTS FROM TYPOLOGICAL RESEARCH
}

\author{
Anne Tamm \\ Hungarian Academy of Sciences, Károli Gáspár University of \\ the Reformed Church in Hungary \\ Piibi-Kai Kivik \\ Indiana University
}

\begin{abstract}
This paper discusses the need for a modern Estonian reference grammar for learners and lays the basic groundwork for creating one. The current abundance of materials for teaching Estonian as a foreign language and recent advancements in both areal-typological linguistics and in the study of acquisition of Estonian contribute to conceptualizing a new type of grammar, and further improving the teaching and learning of Estonian. Modern language instruction orients to proficiency as the ability to use language in real life. We contend that this goal, combined with the availability of language technology and increased mobility of people increases the demands on effective teaching of language structure. Research has shown that the main difficulties for learners of Estonian concern morphology and morphosyntax. We suggest that including an areal-typological perspective on categories and concepts in describing and explaining the structure of Estonian may help learners in these areas.
\end{abstract}

Keywords: areal-typological linguistics, Estonian as foreign language, morphosyntax, categories, learner grammar

DOI: https://doi.org/10.12697/jeful.2017.8.1.14

\section{Introduction}

This article discusses the changing role of pedagogical and reference grammars in teaching Estonian from the perspective of new theoretical and applied research in typology, morphosyntax, and second language learning. There are affinities between functional typology and second language acquisition (SLA), as parallels between typological generalizations and learner behaviour can help make predictions about acquisition order and difficulty (Giacalone Ramat 2009: 258). 
In conceptualizing a modern reference-pedagogical grammar, we discuss the applications of areal-typological research of Estonian morphosyntax to teaching language structure in communicative context.

\section{A pedagogical reference grammar for Estonian?}

From the perspective of European languages, it is unique that Estonian does not have an English-language reference grammar. Furthermore, among the three major Uralic languages of the EU, and the languages of the three Baltic states, Estonian is the only one that has no modern comprehensive reference grammar in English, a fact that is especially baffling in the light of the scope and depth of the linguistic research available on Estonian as well as the abundance of teaching materials. The latter contain detailed and useful grammar reference but are accessible to a limited audience or do not go beyond the basics see the references section for the materials discussed in Metslang et al. 2003, Teral 2015, the online courses Keeleweb2, Keeleklikk and the textbooks "Keel selgeks!" (Rammo et al. 2012) and "Teach Yourself Estonian" (Kingissepp and Kitsnik 2008).

In conceptualizing an Estonian grammar that would fill this lacuna, we concluded that the text will need to provide a comprehensive description of the Estonian system while also be useful for learners. It should be accessible to all university students learning Estonian and appeal to students and scholars of linguistics as well as area studies. It should correspond to the criteria of a quality grammar put forward in the linguistics community (e.g. Rice 2005 and Noonan 2006), as it would be serving as a basic reference work at least for the time that a complete modern reference grammar of Estonian is not yet available. Tauli (1973/1983) and Harms (1962) are valuable volumes but represent earlier eras of linguistics and are, similarly to the modern edited volume by Erelt (2003), not targeted to learners. Pedagogical grammars are different from descriptive grammars. They are hybrids combining linguistic theory and analysis and knowledge of language acquisition (Odlin 1994).

The goal of the envisioned text is twofold: first, to obtain a maximally clear and learner-friendly presentation of the Estonian system; second, to maximally reflect the uniqueness of the language as revealed by current linguistic research. These are not at all contradictory aspirations but will require a fundamentally different approach compared to previous grammars that draws on research in linguistic typology. 


\section{Difficulty and typology}

In order to maximize the effectiveness of L2 instruction, including explicit instruction of form and, specifically, grammar presentation, knowledge about the relative difficulty of specific areas of grammar is important.

Learning difficulty of a feature or subsystem can be defined as linguistic-structural complexity and cognitive complexity. Typological distance from learner's L1 is a factor under linguistic complexity, whereas cognitive complexity, in the context of explicit knowledge, implies that "learning difficulty depends on the properties of the metalinguistic proposition used to describe and explain the form, function, and use of linguistic constructions" (Rodriguez Silva and RoehrBrackin 2016).

The three factors suggested for determining grammatical difficulty are complexity of form, complexity of meaning, and complexity of the form-meaning relationship (DeKeyser 2005). For form-meaning mappings, opaqueness is an issue, as in the case of irregular forms. The more complicated the form-meaning mapping is, the more frequent exposure is needed for learning. Other factors influencing difficulty are perceptibility (lack of salience), communicative value, and the L1 system. In pedagogical contexts, teachers identify difficulty based on performance errors, often intuitively. As found in a recent study (Rodriguez Silva and Roehr-Brackin 2016), the teachers' learning difficulty assessments turned out to have better predictive power about actual difficulty in performance than those by either the learners or the researchers.

For learners of Estonian with background in major European languages, both learner and teacher self-reports have named morphology as the main difficulty (Viilukas 2010, Laakso 2015, Teral 2015). Various morphosyntactic phenomena, such as the verbal categories and the object case alternation are also discussed as common sources of errors (e.g. Metslang et al. 2003: 3). Not surprisingly, inflectional morphology has been the core area of research of Estonian - and other Finno-Ugric languages - as second languages, and the one with the greatest potential for contributions to SLA research (Suni 2012). Laakso (2015: 173) listed "the rich morphology, the fundamental differences in the lexicon, perhaps also certain non-SAE features of the syntax" as central FinnoUgric features to be dealt with in the pedagogy of these languages. 
There is a universal difficulty of morphology in acquisition compared to syntax, which becomes a central issue in richly inflected languages, and this is the complexity of forms (DeKeyser 2005). Nominal case, often topping the list of reported difficulties in Estonian, has been found to present challenges independent of the typological nature of the learners' L1 (Bentz and Winter 2013). In Estonian, the high degree of irregularity adds to the complexity of form-meaning mapping. Here, we examine three factors that affect difficulty in Estonian morphosyntax.

Firstly, the difficulty is likely due to psycho-typology based on the perceived typological distance from L1 (Kellerman 1983). Psychotypological difficulty emerges in cases where L2 or its phenomena are conceptualized as a difficulty by a L1 speaker merely by virtue of the languages being typologically different. This may - but need not - coincide with L2 linguistic complexity, typological distance, and existence or lack of similar phenomena in L1. In instruction, it would be useful to distinguish typological differences that are likely to pose cognitive difficulties in learning from those that are not. A psycho-typological difficulty often receives pedagogical attention, whereas a less clearly perceived typological difficulty remains a problem.

The Estonian case system presents a typical psycho-typological difficulty as the number of cases is seen as a challenge because it is a phenomenon typologically different from most L1s. The small advantage of this perception is that the case system is addressed systematically in instruction. However, the learning of further structures and categories involving case may prove more difficult for some but not other L1 speakers. For instance, Estonian nominal case patterns, such as partitive marking in number phrases (kaks hiir-t [two[NOM] mousePAR] 'two mice') and phrase-internal agreement marking (kahe-le hallile hiire-le [two-ALL grey-ALL mouse-ALL] 'to two grey mice') are problematic for various languages, but for various reasons. Regardless of genealogical relationships, these structures are likely to be easier for Russian learners and somewhat easier for Italians because nouns in number phrases are also case-marked in Russian, and there are comparable partitive constructions in Italian. Case in number phrases is likely to be more difficult for English, Dutch, or Hungarian learners because case does not occur in the number phrases of these languages. Agreement marking appears in the noun phrases of Russian as well as Italian and Dutch, but it may pose problems for English or Hungarian speakers even though Hungarian is famous for its extensive case system. Although Russian learners may find Estonian case psycho-typologically difficult 
and Hungarians have an advantage, we have observed considerable difficulties of agreement in noun phrase in Hungarian L1 learners.

Secondly, difficulty may also be teaching-induced in the instructional setting. The setting and teacher focus can impact the learning process negatively by creating more cognitive load where it is superfluous. Conversation-analytic research of non-pedagogical interactions involving Estonian and Finnish L2 speakers has found that learners (over)focus on suffixes in spontaneous talk. They engage in extensive self-repairs of the grammatical form while the native-speaker interlocutor is ready to move on with topical talk as the meaning has been made clear (Kurhila 2005, Kivik 2012, 2013).

In fact, Laakso (2015) has observed that the main difficulty of acquiring Finno-Ugric languages lies in vocabulary learning, as the number of cognates is reduced compared with major European languages. Additionally, we contend that for learners - as well as linguists - the borderline between grammar and lexicon is not always clearly demarcated. When learners are struggling with stem changes and (plural) partitive endings, they are thinking "grammar" but actually face memory and processing issues not unlike those in learning vocabulary. Therefore, in initial stages, learning unanalyzed phrases enables functional use of complicated structures.

Thirdly, the challenge of Estonian morphosyntax is also a languagespecific categorization phenomenon. Here we speak of differences as in the English, Hungarian, and Russian tenses and aspect. Russian uses morphology (-va as in raskrashival 'was painting') to express the imperfective aspect that is similar to the meaning of the English progressive form as expressed by be $+V$-ing as in Mary is painting the wall. Hungarian uses syntactic means - word order - to express the progressive (felment 'went up' vs ment fel 'was going up'). However, the concept covered by the Russian imperfective aspectual form goes far beyond English or Hungarian progressive forms and extends, for instance, also to genericity. L2 Estonian rich morphology carves up the aspectual conceptual space in a different way compared to each of these languages. Estonian morphosyntax is difficult for learners because there are a number of such mismatches with typical Standard Average European (SAE) languages.

However, there is regularity in the divergences, and the regularity stems from areal factors. In heavily simplified terms, Estonian grammar is part "European" and part "Non-European", that is, typical Northern Eurasian forms are employed to express SAE meanings. The FinnoUgric features - such as a multitude of case endings and a relatively 
high number of non-finite categories, which fall between verbs and nominals - are used to express concepts that resemble European grammatical concepts such as definiteness, aspect, tense, or modality. Since the morphemes functioned earlier as markers for cases or infinitives and they are therefore restricted in their syntactic distribution, Estonian grammar presents regular "false friends" to learners; that is, instead of the usual case of lexical words being the false friends, the grammar system contains categories that only occasionally overlap with the wellknown SAE categories. A typical error is overextension of the Estonian category boundaries to match the category boundaries characteristic of a SAE language.

For instance, the inessive case form and the non-finite verb form -mas as in ujumas 'swimming' is a rather common structure in FinnoUgric languages. It expresses the SAE progressive meanings, as in Mari on ujumas 'Mary is off swimming', which is expressed by be $+V$-ing in English as in Mary is swimming (see Section 6). European L1 speakers frequently overextend the borders of the category covered by the mas construction to fit the English-like progressive. The progressive category is rather expressed by the partitive object case in Estonian. Also, case alternation of objects, typical of Uralic languages, expresses in Estonian the aspectual opposition of (secondary) imperfectives and perfectives as in Slavic languages. The well-attested problem for Russian L1 speakers is that they overextend the object case to match L1 imperfective (see also Section 5 for indefiniteness). However, the diachronic case forms retain restrictions that reflect their role in the earlier, FinnoUgric grammatical system. To learn these semantically hybrid categories is difficult because of the partial match with L1 categories, but it could be easier if the learners were made aware of the regularities.

\section{Structures, categories, and levels of description}

Instruction is likely to profit from a more informed typological approach since both areal versus genealogical belonging yields differences that cause difficulties, as in the example of Russian versus Hungarian case phenomena discussed in Section 3. Awareness of the Finno-Ugric origin of the formal toolkit of Estonian, such as case forms of non-finites that pose restrictions on the grammatical concepts that have been reinforced in contact, such as the progressive or evidentiality, allows addressing learning errors more systematically. This approach is especially beneficial 
if the instruction is informed by the type of the error - grammar proper or lexicon.

We suggest possible solutions to overcome the main difficulties concerning morphology and morphosyntax by using an areal-typological perspective, explaining how the original "Non-European" forms are employed to express categories of typical SAE languages. This is in line with Birute Klaas-Lang's areal-typological approach to morphosyntax, which has also informed her work creating materials for teaching structures in the communicative context. We would like to make this link even more explicit.

Recent research on the typological features of Estonian is rich. In addition to the series "Typological Studies of Estonian" that were published by the University of Tartu in the 1990s, the 21st century has seen useful additions in the form of larger typologically informed volumes: Metslang ed. (2009a) and Erelt ed. (2003) on Estonian. KlaasLang and Norvik (2014) detail the typological features of the Baltic areal; Klaas $(1996,1999)$ analyses the object case. Metslang (2009b, 2009c) helps linking SLA and typology as it inventarizes the main typological features of Estonian in the context of European languages as well as the pitfalls of learning Estonian as L2. The papers on cross-categorial case by R. Pajusalu and Orav (2008) as well as on evidentialityareal and typological views-by Klaas $(1997,2002)$ and Erelt, Metslang, and K. Pajusalu (2006) are relevant for the discussion below.

Recent years have witnessed a debate about categories. Scholars have found that genealogically and geographically distant languages tend to form diverging categories in their grammars. Simultaneously, genealogically diverging languages develop similar categories in areal contact (Haspelmath 2010, Dryer 2006, Newmeyer 2005). We use the insights of this debate for learner grammars and propose that introducing descriptions in terms of these similarities and differences is beneficial for learning.

Clearly explained comparisons and diachronic evidence may help avoid error patterns. For instance, hybrid categories will require, on the one hand, recourse to linguistic typology in explanations and, on the other, abundant cross-referencing between the "traditional" categories known in English and other better-known European languages.

In addition, students are often curious about grammar peculiarities and a quick and ready answer helps them find some inherent logic for memorizing new patterns via association. The "part-European/partNon-European" conceptualization can be a useful strategy here. In 
particular, new patterns can be introduced either as "something that is there in your language already, just think of this: (example)" or "this is something Estonian learned from its neighbours" or "this works in a way that requires more explanation".

In what follows we look at cross-categorial case expressing aspect (Section 5), the progressive, and evidentiality (Section 6) before summarizing our position on teaching grammar in Section 7.

\section{The partitive: aspect and indefiniteness}

Previous research has documented regularities of errors in the use of the object case alternation between total and partitive cases (Pool 2010). Primarily, the problem concerns the aspectual alternation of the object case as in Mari küpsetas koogi 'Mary baked a cake' with a total object versus Mari küpsetas kooki 'Mary was baking a cake' with the partitive marking on the object (for examples of typical errors, see also Metslang et al. 2003: 131).

As noted in our teaching practice, the partitive is often identified as a marker of indefiniteness by speakers of European languages and overgeneralized as such. Erroneous uses of the partitive to mark indefinite objects have been recorded in earlier literature, as in (1).

$\begin{array}{lllll}\text { (1) Tartu ülikool } & \text { anna-b } & \text { üliõpilase-le } & \text { hea-d } \\ \text { T.GEN university[NOM] } & \text { give-3s } & \text { student-ALL } & \text { good-PAR } \\ \text { võimalus-t } & \text { (pro hea } & \text { võimaluse) } & \text { ennast } \\ \text { opportunity-PAR } & \text { pro good.TOT } & \text { opportunity.TOT } & \text { oneself } \\ \text { igakülgselt } & \text { arenda-da } & & \\ \text { many-sided } & \text { develop-DAINF } & & \end{array}$

'The University of Tartu offers a good opportunity to develop one's interests in many ways' (Pool 2010: 239) ${ }^{1}$

Understanding typological phenomena and diachronic processes that affect the partitive helps identify partitive misuses with such verbs as andma 'give', tegema 'do, make' or leidma 'find', which have been found to be frequent (Pool 2010: 239). In addition to the typological features identified in Klaas (1996) that might cause errors in using the partitive from a cross-linguistic perspective, Luraghi and Huumo

1 Glosses, translations, emphases, and other metatext is provided by the authors. 
(2014) discuss the development of indefiniteness from partitives as a possible SAE feature.

Awareness of such diachronic and typological tendencies concerning SAE may help teachers and learners to address systematically such errors as in example (1), the partitive marking of the indefinite ('a good opportunity').

A recent project studying intra-individual variation and development of a Dutch learner of Finnish (Spoelman and Verspoor 2010) shows that the number of case endings in itself is actually not very problematic, as the learner system stabilizes quite early, after an initial state of variability. The difficulties that persist are the choices between the accusative and the partitive (semantics, form-meaning mapping) and the realization of plural partitives (form). Although the Finnish partitive phenomena are not completely identical to the Estonian ones, one can assume that the basic error types by learners of these two areally and genealogically related languages overlap.

\section{Non-finites and case: the progressive-absentive and evidentiality}

We discuss here two more case-related phenomena, Tense-AspectMood (TAM) expressed by case forms of the non-finites, which pose difficulties for learners in our experience. The first one concerns a mismatch in space-time parallels in the TAM system, expressed by spatial inner location and the progressive, and the other one is evidentiality, a missing category in many common L1s. As detailed in the previous section, the difficulties with the object case are well documented because objects occur in most transitive clauses, and the learner must make a choice of form in the obligatory context. The error can be detected and classified easily. The problem with the non-finites is their optionality - there are other ways of expressing functionally similar content. Speakers frequently simplify their grammar when addressing learners, and thus these forms are infrequent or missing from the input. This leads to avoidance by the learners of the evidential expressed by -vat or -mas. The use of these forms depends heavily on pragmatics, for example, persuasive strategies, thus the non-targetlike use is not always obvious. Therefore teachers and learners are not well aware of the difficulty these structures may be present. 
The -mas-construction containing a locative (inessive) case form represents a category between verbs and nominals (non-finite, infinitive, supine). Bilinguals, whose Estonian is heavily influenced by English and L1 English learners may overgeneralize its use to the progressive (Peeter on lõunat söömas, incorrectly formed to express 'Peter is eating lunch'). In Estonian, the progressive meaning is expressed by the partitive object Peeter sööb lõunat 'Peter is eating lunch'. The expression with -mas in Estonian indeed means that Peter is eating lunch, but it also implies that the event happens at another location and not in the vicinity of either the speaker or the hearer of the utterance. Peeter on lounat söömas 'Peter is away, eating lunch' implies that Peter is not eating in the deictic centre. This construction corresponds to the absentives of many European languages such as German or Dutch, where absentives and progressives are expressed by separate forms, e.g., Peter ist essen versus Peter ist am Essen (see Tamm 2011). The constructions convey a different Vendlerian Aktionsart or event type (Vendler 1957) since the Estonian category is stative and not a process or action. This difference requires extra attention in teaching.

One problem of the optional category of the evidential expressed by -vat is that its name is misleading for the teacher (not to mention the linguistically naïve learner). In many sources it is referred to as the Quotative. However, we cannot form a rule for the learner "use it when the information is quoted" because typical citations rarely employ the category. Another term is Oblique; however, the evidential does not typically occur in oblique environments of subordinate clauses where major European languages realize obliques.

In order to explain the advantages of using the evidential, the grammar can draw a parallel with a similar discourse phenomenon in English, where, for instance, the passive serves the strategic goal of obscuring or minimizing the agent: A man was shot in our street yesterday versus I shot a man in our street yesterday. An evidential may serve a similar goal of suppressing information in Estonian, as in Meie tänaval olevat eile üks mees surma saanud 'A man was killed in our street yesterday, they say'. In this case, not only the lack of agency but also a lack of witnessing is suggested by the speaker, yielding a stronger degree of detachment from the event.

Explaining the use of the evidential or the progressive in terms of discourse pragmatics would be helpful. Their historical origin as case forms of non-finites as a regular pattern and drawing parallels with modality and related categories in European languages, such as the Baltic languages in case of the evidential (cf. Klaas 1997) can be useful. 


\section{The role of a grammar in teaching Estonian as a second/foreign language}

It may seem counterintuitive to focus on grammar in the situation where the need to teach interaction and real-life language use has been made explicit (Suni 2012, Klaas-Lang et al. 2015, Teral 2015). In the pedagogy of Estonian as well as other Finno-Ugric languages, there has been a shift away from formalist, morphosyntax-centred approaches towards functionalism (Pool 2010, Suni 2012).

We contend that this very shift necessitates (re-)engagement with instruction and presentation of the linguistic structure. A similar argument concerning metalinguistic instruction has been made by Kruse (2014) in defence of instructed language learning in the era of abundant self-study options.

The issue of explicit teaching of grammar has been subject to numerous studies (cf. an overview in Kruse 2014). Research into metalinguistic knowledge has suggested a beneficial effect for L2 learning (e.g. Roehr-Brackin 2015) and there is ample evidence that explicit learning (i.e. conscious attention, hypothesis testing) is useful for adult learners (meta-analyses by Norris and Ortega 2000, Spada and Tomita 2010) although it needs to be supported by implicit learning (i.e. acquisition "without conscious operations", Ellis 2015) for long-term effects (MacWhinney 2015).

While recent research emphasizes input and use in L2 learning (e.g. Eskildsen and Cadierno, 2015), being limited to input only has several risk factors for adult L2 learners, including entrenchment, negative transfer, and parasitism, i.e., accessing L2 meanings solely through translations to L1 (MacWhinney 2015). Among the remedies, focused training and targeted support are important. As noted by CintrónValentín and Ellis (2016: 19) in an experimental study demonstrating the effect of explicit grammar teaching of English verb tense morphology to L1 Chinese speakers, "the forms that need to be attended are often the least salient in the input." To draw a parallel with grammar-writing, Noonan (2006: 356) observed that not enough grammars "explicitly note the absence of commonly encountered grammatical features in the languages they are describing." In the case of Estonian, nominal case endings, especially in the semantically opaque forms such as the partitive as well as the lack of verbal agreement morphology in negation are both not salient and typologically challenging, resulting in persistent error patterns (Kitsnik 2007, Pool 2010). 
The extent to which explicit instruction of structure is needed also depends on the needs of the learners. At present, the learners of Estonian are a more diverse group than ever before. Learners of Estonian as a foreign language include those with linguistic interests but also those with personal needs to know the language. However, Laakso laments the fact that there are "very little diversified teaching materials available" (2015: 186).

Teaching of Estonian as a second language to local Russian L1 speakers has of course been the central focus in the development of target language materials and methods. In comparison with materials available for most less commonly taught languages in the world, recent work in this area has resulted in an impressive selection of textbooks and online materials for L2 Estonian, which are not only oriented to the Russian learners. The materials co-authored by Klaas-Lang occupy a central place among these, e.g. the textbooks "Keel Selgeks!" and "Teach Yourself Estonian", Oneness and Keeleweb2 language portals.

We believe that in addition to the learners already motivated to learn about the system of Estonian, the instrumentally motivated learner audience, oriented to functional proficiency, stand to benefit from metalinguistic information in a grammar as well, albeit indirectly. Directly, it is their teacher who can use the information to make better choices about teaching, from developing curricula to providing corrective feedback in classroom. As we argue here, the metalinguistic information could (and in some cases should) include explicit typological comparisons.

Laakso has observed that "there is very little research on how the awareness of distant relatedness or the knowledge of the history or prehistory of the target language really affects your learning" (2015: 185). Language instructors, however, have abundant anecdotal evidence of how such explanations are welcomed by students. As an example of emergent research, Viilukas (2010) presents a study of illustrating principles of consonant gradation in Estonian that helps students. We agree with Laakso that it is most beneficial to make these typological or diachronic connections in the discussion of some specific feature structure or vocabulary area.

Within the field of communicatively oriented language teaching, there are still misperceptions and misapplications regarding the teaching of grammar that go back to the earlier version of the approach, which eschewed systematic presentations of grammar and often resulted in low accuracy in learners. Viilukas (2010: 54) in her critique of a popular Estonian textbook, observes that the grammar sections lack 
explanations, "typically of communicative language teaching method." When language is at all taught with a proficiency (e.g. actual real-life use) goal in mind, lengthy grammar explanations should indeed not take the place of communicative practice and a grammar should be seen as the resource for meaningful use. At the same time, explanations and metalinguistic knowledge should be available for the learners. We concur with Viilukas (2010: 100, cf. Kruse 2014) in that it is important to try and give an answer to the learner's question "why?" as the explanation may help to master a linguistic phenomenon missing from the $\mathrm{L} 1$ or at least minimize the anxiety about learning a typologically very different language.

Communicative language teaching, when it is truly aimed at achieving proficiency, does not neglect teaching structure but contextualizes it, ties structure to meaning and function, and, especially in a foreign language situation, moves explicit teaching and learning of grammar rules increasingly out of classroom, prioritizing active use and practice. Thus the fact that (some) learners need explicit grammar explanations does not discredit communicative teaching of morphologically complex languages; it just indicates the need for diverse materials and approaches. Not surprisingly, the criteria that linguists have suggested for quality grammar writing can be applied to quality grammar teaching, for example the requirement not to just describe a feature but also conditions for its use, give indications of the frequency of grammatical constructs, and to "describe morphology with a formto-function orientation and syntax with a function-to-form orientation" (Noonan 2006: 359).

In sum, using the insights from the venerable tradition of grammar writing from a typological, contrastive, comparative, and historical perspective can boost the effectiveness of communicative methods in teaching morphosyntactically complex languages with systematically hybrid categories such as Estonian.

\section{Conclusions}

We have tried to make explicit how areal-typological research can benefit the practice of teaching Estonian as a second /foreign language. We believe that a reference-pedagogical grammar for Estonian could tie the loose ends and integrate the insights from earlier studies on teaching methods as well as areal and typological research. 
As Ellis has noted, "the human mind is built to integrate new information in a way that is maximally compatible with established knowledge - consequently, L1-attuned expectations and selective attention bias L2 acquisition" (Ellis 2015: 61). Without advocating a return to the contrastive hypothesis, which claimed L1 determines how L2 is learned, we believe integrating observations from areal-typological studies provides an additional dimension for learning languages, especially Estonian with its various cross-linguistic influences.

We agree with Pool (2010) that the universals as well as specifics of learning Estonian as L2 with various languages as L1s should be studied, and that it makes sense to incorporate acquisition studies in further developments of teaching methodology (Pool 2010: 10-11). Possible connections with linguistic-typological research may emerge from these. We have identified learners' difficulties related to systematic typological peculiarities in the structure of Estonian morphosyntax (cross-categorial case) and its mappings to semantics (overlapping and missing categories) and use. We suggest that since the use of several of these forms is pragmatically restricted, it is helpful for the learner to be aware of the regularity in the mismatches with their previously acquired linguistic systems. We propose that in the teaching and learning process, attention is directed to the pragmatics of these "in-between" forms.

The changing nature of foreign language instruction (online and hybrid courses), availability of language technology (e.g. translation engines), and increased mobility of people, both native speakers and learners of Estonian, make self-study of the language (both "in the wild" and in combination with instruction) ever more relevant. Thus clear and accessible presentations of the core structures and their use are sorely needed. The learner grammar project is envisioned as part of such an endeavour while also contributing to making information about the structure of Estonian and its typological features more accessible to readers whose language typologically diverges from Estonian.

Clearly, more empirical studies are needed of the acquisition of Estonian to see how language instruction helps address the cognitive challenges of learning the complexity of Estonian morphosyntax and hybrid categories. Both further explorations of corpora, as well as experimental research, and comparisons of teaching approaches and methods would help shed light upon which methods - or combinations of them - serve the current diversified pool of new learner types. 


\section{Acknowledgements}

An earlier of version of the article was presented at the AABS annual conference in May 2016 and we are grateful to the organizers and audience. Anne Tamm acknowledges the support of Languages under the Influence. Uralic syntax changing in an asymmetrical contact situation (OTKA 118079), PI Katalin É. Kiss.

\section{Addresses:}

Anne Tamm

Hungarian Academy of Sciences

Research Institute for Linguistics

Benczúr utca 33

H-1068 Budapest, Hungary

E-mail:TammA@ceu.edu

Department of Netherlandic Studies

Károli Gáspár University of the Reformed Church in Hungary

Faculty of Humanities

Institute of German and Netherlandic Studies

Reviczky str. 4. Room 203

H-1088 Budapest, Hungary

Piibi-Kai Kivik

Indiana University, Bloomington

Department of Central Eurasian Studies

School of Global and International Studies

The Global and International Studies Building

355 North Jordan Avenue

IN 47405-1105 Bloomington, USA

E-mail: pkivik@indiana.edu

\section{References}

Bentz, Christian and Bodo Winter (2013) "Languages with more second language learners tend to lose nominal case". Language Dynamics and Change 3, 1, 31-27.

Cintrón-Valentín Myrna C. and Nick C. Ellis (2016) "Salience in second language acquisition: physical form, learner attention, and instructional focus". Frontiers of Psychology 7, 1284, 1-21. doi: 10.3389/fpsyg.2016.01284 
DeKeyser, Robert (2005) "What makes second-language grammar difficult? A review of issues". Language Learning 55, Supplement 1, 1-25.

Dryer, Matthew S. (2006) "Descriptive theories, explanatory theories, and basic linguistic theory". In Felix Ameka, Alan Dench, and Nicholas Evans, eds. Catching language: Issues in grammar writing, 207-234. Berlin: Mouton de Gruyter.

Ellis, Nick (2015) "Implicit AND explicit language learning: their dynamic interface and complexity". In Patrick Rebuschat, ed. Implicit and explicit learning of languages, 3-23. Amsterdam: John Benjamins.

Erelt, Mati (ed.) (2003) Estonian language. (Linguistica Uralica Supplementary Series, Volume 1.) Tallinn: Estonian Academy Publishers.

Erelt, Mati, Helle Metslang, and Karl Pajusalu (2006) "Tense and evidentiality in Estonian”. In Bert Cornillie and Nicole Delbecque, eds. Topics in subjectification and modalization, 125-136. (Belgian Journal of Linguistics 20.) Amsterdam: John Benjamins.

Eskildsen, Søren Wind and Teresa Cadierno (2015) “Advancing usage-based approaches to L2 studies”. In Teresa Cadierno and Søren Wind Eskildsen, eds. Usage-based perspectives on second language learning, 1-16. Berlin: Mouton de Gruyter.

Giacalone Ramat, Anna (2009) "Typological universals and second language acquisition”. In Sergio Scalise, Elisabetta Magni, and Antonietta Bisetto, eds. Universals of language today, 253-272. Amsterdam: Springer.

Harms, Robert T. (1962) Estonian grammar. Indiana University Publications: Uralic and Altaic Series 12 [reprinted by Routledge, 1997].

Haspelmath, Martin (2010) "Comparative concepts and descriptive categories in crosslinguistic studies". Language 86, 3, 663-687.

Keeleklikk $=$ Available online at $<$ https://www.keeleklikk.ee/et/welcome $>$. Accessed on 22. 01.2017.

Keeleweb2 = Available online at $<\mathrm{http} / / \mathrm{www} \cdot$ ut.ee/keeleweb2/ $>$. Accessed on 22.01.2017.

Kellerman, Eric (1983) “Now you see it now you don't.” In Susan M. Gass and Larry Selinker, eds. Language transfer in language learning, 112-134. Rowley: Newbury House.

Kitsnik, Mare (2007) "Eesti keele kui teise keele õppija kõrvalekalded eituse väljendamisel”. In Pille Eslon, ed. Tallinna Ülikooli keelekorpuste optimaalsus, töötlemine ja kasutamine, 152-181. (Tallinna Ülikooli eesti filoloogia toimetised 9.) Tallinn: Tallinna Ülikool.

Kitsnik, Mare and Leelo Kingisepp (2008) Teach yourself Estonian. London: Hodder \& Stoughton.

Kivik, Piibi-Kai (2012) Conversation-for-learning in Estonian coffee-hour: an interactional linguistics perspective. Unpublished $\mathrm{PhD}$ dissertation. Indiana University, Bloomington.

Kivik, Piibi-Kai (2013) "Micromanaging (with) morphemes: language pedagogy and social order in conversation-for-learning." Paper presented at Thinking, doing, learning: Usage-based approaches to second language learning. University of Southern Denmark, Odense, Denmark. 
Klaas, Birute (1996) "Similarities in case marking of syntactic relations in Estonian and Lithuanian." In Mati Erelt, ed. Estonian: Typological Studies 1, 37-67. (Tartu Ülikooli eesti keele õppetooli toimetised 4.) Tartu.

Klaas, Birute (1997) "The quotative mood in the Baltic Sea areal”. In Mati Erelt, ed. Estonian: Typological Studies II, 73-97. (Tartu Ülikooli eesti keele õppetooli toimetised 8.) Tartu.

Klaas, Birute (1999) "Dependence of the object case on the semantics of the verb in Estonia, Finnish and Lithuanian". In Mati Erelt, ed. Estonian: Typological Studies III, 47-83. (Tartu Ülikooli eesti keele õppetooli toimetised 11.) Tartu.

Klaas, Birute (2002) "Reported commands in Lithuanian compared to Estonian". Linguistica Uralica XXXVIII, 2, 118-124.

Klaas-Lang, Birute and Miina Norvik (2014) "Balti areaali tüpoloogilisi sarnasusi morfosüntaksi valdkonnas." Keel ja Kirjandus 8-9, 590-608.

Klaas-Lang, Birute, Kristiina Praakli, Tiina Kikerpill, Ilze Zagorska, and Ülle Türk (2015) Eesti, Läti, Leedu, Soome, Kanada ja Iirimaa riigikeeleõppe võrdlev uuring. Tartu Ülikool: Eesti ja üldkeeleteaduse instituut.

Kruse, Mari (2014) "Võõrkeeleõpe kui sotsiaalne, sünergiline ja teadvustatud protsess". In Silvi Tenjes ja Raili Pool, eds. Foreign Language Learning, 37-56. (Eesti ja soome-ugri keeleteaduse ajakiri. Journal of Estonian and Finno-Ugric Linguistics 5(3).) Tartu: University of Tartu Press.

DOI: http://dx.doi.org/10.12697/jeful.2014.5.3.02

Kurhila, Salla (2005) "Different orientations to grammatical correctness." In Keith Richards and Paul Seedhouse, eds. Applying conversation analysis, 143-158. New York, NY: Palgrave Macmillan.

Laakso, Johanna (2015) "The Finno-Ugric foundations of language teaching". In Johanna Laakso, Maria-Maren Sepper, Kirsti Siitonen, and Katre Õim, eds. Lähivõrdlusi. Lähivertailuja 25, 172-190. Tallinn: Eesti Rakenduslingvistika Ühing. DOI 10.5128/LV.1736-9290.

Luraghi, Silvia and Tuomas Huumo, eds. (2014) Partitive cases and related categories. Berlin/New York: Mouton De Gruyter.

MacWhinney, Brian (2015) "Multidimensional SLA". In Søren Wind Eskildsen and Teresa Cadierno, eds. Usage-based perspectives on second language learning, 19-48. Berlin: Mouton de Gruyter.

Metslang, Helle (2009a) "Estonian grammar between Finnic and SAE: some comparisons." Language Typology and Universals, 49-71.

Metslang, Helle (2009b) “The pitfalls of a language: Estonian as L2”. In M.M. Jocelyne Fernandez-Vest and Danh Thanh Do-Hurinville, eds. Plurilinguisme et traductiondes enjeux pour l'Europe, 119-134. (Collection Grammaire \& Cognition 6) Paris: L'Harmattan.

Metslang, Helle, ed. (2009) Sprachtypologie und Universalienforschung = Language Typology and Universals, vol. 62, 1-2. Berlin: Akademie Verlag. http://dx.doi.org/10.1524/stuf.2009.0004. 
Metslang, Helle, Ingrid Krall, Renate Pajusalu, Kristi Saarso, Elle Sõrmus, and Silvi Vare (2003) Keelehärm: eesti keele probleemseid piirkondi. Tallinn: Tallinna Pedagoogikaülikooli Kirjastus.

Newmeyer, Frederick J. (2005) Possible and probable languages: A generative perspective on linguistic typology. Oxford: Oxford University Press.

Norris, John and Lourdes Ortega (2000) "Effectiveness of L2 instruction: A research synthesis and quantitative meta-analysis". Language Learning 50, 417-528.

Noonan, Michael (2006) "Grammar writing for a grammar-reading audience". Studies in Language 30, 2, 351-365.

Oneness $=$ Available online at $<$ http://www.ut.ee/keeleweb2/kursused/oneness $>$. Accessed on 22.01.2017.

Pajusalu, Renate and Heili Orav (2008) "Supiinid koha väljendajana: liikumissündmuse keelendamise asümmeetriast”. In Mati Erelt, ed. Emakeele Seltsi Aastaraamat 53, 104-121. Teaduste Akadeemia Kirjastus.

Pool, Raili (2010) "Eesti keele teise keelena uurimine Tartu Ülikoolis - hetkeseis ja perspektiivid". Silvi Tenjes, toim. Eesti ja soome-ugri keeleteaduse ajakiri. Journal of Estonian and Finno-Ugric Linguistics 1, 5-19. Tartu: Tartu Ülikooli Kirjastus.

Rammo, Sirje, Maarika Teral, Birute Klaas-Lang and Mari Allik (2012) Keel selgeks! Eesti keele õpik täiskasvanutele. Estonian grammar. Eesti keele grammatika. Tallinn: Avita.

Rice, Keren (2005) “A typology of good grammars". Studies in Language 30, 2, 385-405.

Rodriguez Silva, Luis H. and Karen Roehr-Brackin (2016) "Perceived learning difficulty and actual performance: Explicit and implicit knowledge of L2 English grammar points among instructed adult learners". Studies in Second Language Acquisition 3, 2, 317-340.

Roehr-Brackin, Karen (2015) "Long-term development in an instructed adult L2 learner: Usage-based and complexity theory applied". In Søren Wind Eskildsen and Teresa Cadierno, eds. Usage-based perspectives on second language learning, 181-206. Berlin: Mouton de Gruyter.

Spada, Nina and Tomita Yasuyo (2010) "Interactions between type of instruction and type of language feature: a meta-analysis". Language Learning 60, 2, 263-308.

Spoelman, Marianne and Marjolijn Verspoor (2010) "Dynamic patterns in development of accuracy and complexity: A longitudinal case study in the acquisition of Finnish". Applied Linguistics 31, 4, 532-553. http://dx.doi.org/10.1093/applin/amq001.

Suni, Minna (2012) "The impact of Finno-Ugric languages in second language research: Looking back and setting goals.” Lähivõrdlusi. Lähivertailuja 22, 407-438. http://dx.doi.org/10.5128/LV22.14

Odlin, Terence (1994) "Introduction". In Terence Odlin, ed. Perspectives on pedagogical grammar, 1-22. Cambridge: Cambridge University Press.

Tamm, Anne (2009) "The Estonian partitive evidential: Some notes on the semantic parallels between the aspect and evidential categories". In Lotte Hogeweg, Helen de Hoop, and Andrey Mal'chukov, eds. Papers from TAM TAM: Cross-linguistic semantics of Tense, Aspect, and Modality. Amsterdam: Benjamins, 365-401. 
Tamm, Anne (2011) "Cross-categorial spatial case in the Finnic non-finite system: focus on the absentive TAM semantics and pragmatics of the Estonian inessive m-formative non-finites". Linguistics: An Interdisciplinary Journal of the Language Sciences 49, 4, 835-944.

Tauli, Valter (1973/1983) Standard Estonian grammar: phonology, morphology, wordformation, I-II. Stockholm: Almquist \& Wiksell.

Teral, Maarika (2015) Arvutipõhine eesti keele õpe: vahendid ja hinnangud nende efektiivsusele Tartu Ülikooli keelekursuste näitel. (Dissertationes philologiae estonicae Universitatis Tartuensis 37.) Tartu: Tartu Ülikooli Kirjastus.

Vendler, Zeno (1957) "Verbs and times". The Philosophical Review 66, 2, 143-160.

Viilukas, Triinu (2010) Eesti keel võorkeelena ja astmevaheldus algkursusel ehk astmete vahel udus. MA thesis. University of Vienna. Available online at $<$ http://othes.univie.ac.at/9174/>. Accessed on 22. 01.2017.

\begin{abstract}
Kokkuvõte. Anne Tamm, Piibi-Kai Kivik: Grammatika eesti keele õppijale: võõrkeeleõpe ja tüpoloogia. Artikkel osutab ühisosale areaal-tüpoloogilise keeleteaduse ja teise keele omandamise uurimise vahel. Eesti keele morfosüntaks ja süntaks, sh evidentsiaalsuse, aspekti ja eituse väljendamine pakub huvi mõlema ala uurijatele. Keeleõppija jaoks pole siin tegu mitte ainult uue vormi, vaid ka uue grammatilise kategooria või moodustussüsteemiga (nt eitus), kus erinevuste teadvustamine, sh metalingvistiline teadlikkus võib aidata vältida vigu ja kiirendada keeleomandamise protsessi. Artikkel väidab, et kaasaegne kommunikatiivne, suhtluspädevusele suunatud keeleõpe ei väldi grammatika õpetamist, vaid teeb seda läbimõeldult ja kontekstis. Et keeletundides kasutataks võimalikult palju aega suhtlemise harjutamiseks, on vaja käepäraseid ja ammendavaid materjale iseseisvaks tööks, sh grammatikaseletusi ja pedagoogilist grammatikat. Pedagoogiline grammatika, mis põhineb lingvistilisel uurimistööl, pakub uusi võimalusi nii õpetajale kui õppijale sihtja lähtekeele kõrvutamiseks ning veaohtlike või keerulisemate keelenähtuste paremaks omandamiseks.
\end{abstract}

Märksõnad: areaal-tüpoloogiline keeleteadus, eesti keel võõrkeelena, morfosüntaks, kategooriad, õppijagrammatika 